\title{
EXPERIMENTAL INVESTIGATION ON TORSIONAL BEHAVIOR OF COMPOSITE BEAMS REINFORCED WITH TWO-PIECE ENCLOSED STIRRUPS
}

\author{
Zhi Zhang ${ }^{12}$, Qing Wang ${ }^{1}$, Feng Lin ${ }^{1}$ \\ 1 Department of Structural Engineering, College of Civil Engineering, Tongji University, Shanghai \\ 200092, China; \\ 2 Tianjin University Research Institute of Architectural Design \& Urban Planning, Tianjin 300073, China \\ E-mails: zhangzhigood@126.com,071180@tongji.edu.cn,lin_feng@tongji.edu.cn

\begin{abstract}
This paper presents an investigation of the torsional behavior of reinforced concrete (RC) beams which were cast twice and reinforced with two-piece enclosed stirrups. Their torsional behavior was compared with those of monolithically cast $R C$ beams with conventional stirrups using a customized test setup. The test program was divided into two groups to distinguish different influencing factors. Results from the first test group indicated that the maximum torques of monolithically cast beams reinforced with two-piece enclosed stirrups decreased by an average of 3.7\% compared to those reinforced with conventional stirrups. The second test group revealed that the maximum torques of composite beams increased by $6.7 \%$ compared to those of monolithically cast beams. As a whole, minor differences in the maximum torques and deformation capacities were found between composite beams reinforced with two-piece enclosed stirrups and monolithically cast beams reinforced with conventional stirrups.
\end{abstract}

Keywords: RC beam, Composite beam, Two-piece enclosed stirrup, Maximum torque, Experimental study.

\section{INTRODUCTION}

Precast concrete structures have been widely constructed in civil engineering including buildings, bridges and coastal facilities [1-3]. In practice, a specific technique using two-piece enclosed stirrups has been often used for construction efficiency. Fig. 1 illustrates the configuration and construction procedure of a reinforced concrete (RC) girder using such technique. A two-piece enclosed stirrup is composed of a U-stirrup and a crosstie. Before transportation to a construction site, the U-stirrups are embedded in the precast RC girders and then, once on the construction site, they are enclosed by the crossties after longitudinal reinforcement is positioned. The crossties are manually fastened on the top of the U-stirrups using fine wire. Usually, neither welding nor other enhancing detailing is needed to connect the twopiece stirrups. Thus, the two-piece enclosed stirrup is easier to position after setting up the upper longitudinal reinforcement on a construction site when compared to the conventional one-piece enclosed stirrups illustrated in Fig. 2. Following this construction procedure, girders or beams are cast twice and produced to form composite members. Construction formwork is greatly reduced and construction speed is accelerated. Thus, composite beams using two-piece enclosed stirrups have been applied worldwide, e.g., in North America, Japan, Taiwan and mainland China.

Flexural behavior of beams reinforced with two-piece enclosed stirrups and compressive steel bars was studied in [4]. Similarly, torsional behavior is also of concern when the beams are expected to resist torsion. Two differences in configuration exist between beams using two-piece enclosed stirrups and those using conventional one-piece enclosed stirrups, which can detrimentally affect torsional behavior of the beams under consideration. The first difference is that a U-stirrup and a crosstie connect each other in 
two positions, while the conventional one-piece enclosed stirrup has only one connection. Potentially, the integrated tension in the stirrups, which is motivated to resist pure torsion, can be impaired. The second difference is the presence of a naturally formed interface between the first and second cast concrete beam, which can possibly lead to early cracking in beams under torsion.

Historically, efforts have been made to understand the behavior of monolithically cast RC beams under torsion. Their torsional behavior can be interpreted using analytical models which were divided into two principal categories: i) the skew bending theory $[5,6]$, which was the basis of the American Code between 1971 and 1995, and ii) the space truss analogy (STA) [7-9], which is the basis of the European Model Code since 1978, the American Code since 1995 and the Chinese code since 1989. The STA was later developed to the variable angle truss model (VATM) with consideration of the softening effect of concrete by Hsu and Mo [10]. Recently, several experimental and analytical works improved the understanding of torsional behavior of beams [11-14]. However, these analytical approaches did not consider the abovementioned specific configuration of the beams associated with two-piece enclosed stirrups and concrete-to-concrete interface. Consequently, understanding torsion to the point that a quantitative prediction of torsional behavior could be made with confidence was not possible. To remediate this lack of confidence, systemic experimental studies were conducted to investigate torsional behavior of the beams using two-piece enclosed stirrups. Two test groups were used with consideration of the individual specificities in the configuration of the beams.
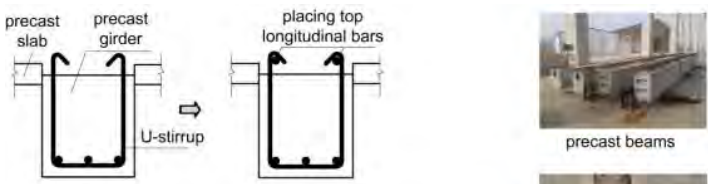

$\sqrt{1}$
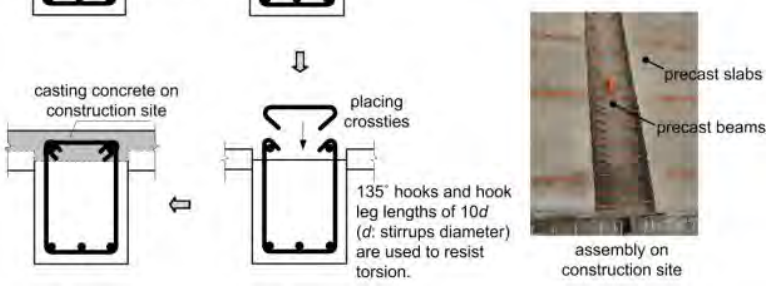

Fig. 1 Configuration and construction procedure of a girder using two-piece enclosed stirrups

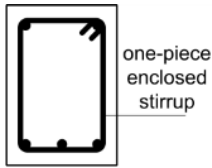

Fig. 2 Conventional stirrups used in RC beams

\section{EXPERIMENTAL PROGRAM}

Two test groups were designed to highlight the effect of configurational differences on torsional behavior. The specimens in the two test groups were successively produced. Table 1 presents the specimen details. The dimension of all specimens is uniformly of $1500 \mathrm{~mm}$ length with a cross sectional size of $150 \mathrm{~mm} \times 250 \mathrm{~mm}$. The first test group includes 12 monolithically cast specimens with the test variables of stirrup form and reinforcement ratio. Three stirrup forms were considered, i.e., the two-piece enclosed stirrup, conventional stirrup and U-stirrup, denoted as A-, B- and C-series specimens, respectively. The torsion resistance of the beams reinforced with U-stirrups can be regarded as lower 
limit in cases of unreliable connections of the U-stirrups and crossties. Different combinations of the transverse and longitudinal reinforcements were used in accordance with the Chinese code [15] to implement three torsional failure patterns, i.e., appropriately reinforced, overreinforced and partially overreinforced failures. Generally, the appropriately reinforced failure pattern occurs when all stirrups and longitudinal reinforcement yield prior to the crushing of concrete. The overreinforced and partially overreinforced failures mean that both types of reinforcements, or, one type of them, did not yield at the crushing of concrete, respectively. The second test group contains eight beams, which were all reinforced with two-piece enclosed stirrups. The test variables were number of casting times and the reinforcement ratio. The D-series specimens were monolithically cast while the E-series specimens were cast twice to build composite members, which are actually used in practice. Each cast height in the E-series specimens was about $125 \mathrm{~mm}$. Note that the specimens indicated with number 1 (i.e., specimen no. A1, B1, C1, D1 and E1) have identical reinforcement, and the same cases are applicable for those indicated with numbers 2,3 , and 4, respectively. Based on test groupings, it was evident that in the first test group, the effect of different stirrup forms on torsional behavior of monolithically cast beams was investigated. In the second test group, the effect of castings on the torsional behavior of the beams was of concern. Consistent combinations of reinforcement ratios were adopted in two test groups for the convenience of comparisons.

Table 1. Specimen details

\begin{tabular}{|c|c|c|c|c|c|c|c|}
\hline $\begin{array}{l}\text { Test } \\
\text { group }\end{array}$ & $\begin{array}{c}\text { Specimen } \\
\text { series }\end{array}$ & $\begin{array}{l}\text { Stirrup } \\
\text { form }\end{array}$ & $\begin{array}{l}\text { Number ofs } \\
\text { casting } \\
\text { time }\end{array}$ & $\begin{array}{l}\text { ecimen } \\
\text { no. }\end{array}$ & $\begin{array}{c}\text { Longitudinal } \\
\text { reinforcement } \\
\text { (reinforcement } \\
\text { ratio) } \\
\end{array}$ & $\begin{array}{c}\text { Stirrup } \\
\text { (reinforcement } \\
\text { ratio) }\end{array}$ & Failure pattern \\
\hline \multirow[t]{12}{*}{1} & A-series & \multirow{4}{*}{$\begin{array}{c}\text { Conven- } \\
\text { tional }\end{array}$} & \multirow{4}{*}{ Monolithic } & A1 & 4D12 (1.21\%) & D10@70 (1.50\%) & Appr. reinforced \\
\hline & \multirow{3}{*}{7} & & & A2 & 4D12 (1.21\%) & D10@120(0.87\%) & \multirow{3}{*}{$\begin{array}{c}\text { Appr. reinforced } \\
\text { Overreinforced } \\
\text { Partially } \\
\text { overreinforced }\end{array}$} \\
\hline & & & & A3 & 4D16 (2.14\%) & D12@60 (2.51\%) & \\
\hline & & & & A4 & 4D12 (1.21\%) & D8@140 (0.48\%) & \\
\hline & \multirow{4}{*}{$\begin{array}{l}\text { B-series } \\
\text { n }\end{array}$} & \multirow{4}{*}{\multicolumn{2}{|c|}{$\begin{array}{l}\text { Two-pieceMonolithic } \\
\text { enclosed } \\
\text { stirrup }\end{array}$}} & B1 & 4D12 (1.21\%) & D10@70 (1.50\%) & \multirow{4}{*}{$\begin{array}{c}\text { Appr. reinforced } \\
\text { Appr. reinforced } \\
\text { Overreinforced } \\
\text { Partially } \\
\text { overreinforced }\end{array}$} \\
\hline & & & & B2 & 4D12 (1.21\%) & D10@120(0.87\%) & \\
\hline & & & & B3 & 4D16 (2.14\%) & D12@60(2.51\%) & \\
\hline & & & & B4 & 4D12 (1.21\%) & D8@140 (0.48\%) & \\
\hline & \multirow[t]{4}{*}{ C-series } & \multirow{4}{*}{\multicolumn{2}{|c|}{ U-stirrup Monolithic }} & $\mathrm{C} 1$ & 4D12 (1.21\%) & D10@70 (1.50\%) & \multirow{4}{*}{$\begin{array}{c}\text { Appr. reinforced } \\
\text { Appr. reinforced } \\
\text { Overreinforced } \\
\text { Partially } \\
\text { overreinforced }\end{array}$} \\
\hline & & & & $\mathrm{C} 2$ & 4D12 (1.21\%) & D10@120(0.87\%) & \\
\hline & & & & $\mathrm{C} 3$ & 4D16 (2.14\%) & D12@60(2.51\%) & \\
\hline & & & & $\mathrm{C} 4$ & 4D12 (1.21\%) & D8@140 (0.48\%) & \\
\hline \multirow[t]{8}{*}{2} & \multirow{4}{*}{ D-series } & \multirow{4}{*}{\multicolumn{2}{|c|}{$\begin{array}{l}\text { Two-pieceMonolithic } \\
\text { enclosed } \\
\text { stirrup }\end{array}$}} & D1 & 4D12 (1.21\%) & D10@70 (1.50\%) & \multirow{4}{*}{$\begin{array}{c}\text { Appr. reinforced } \\
\text { Appr. reinforced } \\
\text { Overreinforced } \\
\text { Partially } \\
\text { overreinforced }\end{array}$} \\
\hline & & & & D2 & 4D12 (1.21\%) & D10@120(0.87\%) & \\
\hline & & & & D3 & 4D16 (2.14\%) & D12@60(2.51\%) & \\
\hline & & & & D4 & 4D12 (1.21\%) & D8@140 (0.48\%) & \\
\hline & \multirow{4}{*}{$\begin{array}{c}\text { E-series } \\
N \geqslant\end{array}$} & \multirow{4}{*}{\multicolumn{2}{|c|}{$\begin{array}{l}\text { Two-piece Cast twice } \\
\text { enclosed } \\
\text { stirrup }\end{array}$}} & E1 & 4D12 (1.21\%) & D10@70 (1.50\%) & Appr. reinforced \\
\hline & & & & E2 & 4D12 (1.21\%) & D10@120(0.87\%) & Appr. reinforced \\
\hline & & & & E3 & 4D16 (2.14\%) & D12@60(2.51\%) & Overreinforced \\
\hline & & & & E4 & 4D12 (1.21\%) & D8@140 (0.48\%) & $\begin{array}{c}\text { Partially } \\
\text { overreinforced }\end{array}$ \\
\hline
\end{tabular}

For each specimen, the stirrup spacing lists in Table 1 was used for its middle part of $500 \mathrm{~mm}$ length. The stirrup spacing decreased by half from both ends of the $500 \mathrm{~mm}$ length, as illustrated in Fig. 3. By 
doing this, the failure was limited in the beam's middle part as far as possible for the convenience of monitoring angles of twist. Besides, the hook angle of $135^{\circ}$ and hook leg lengths of $10 d$ ( $d$ denotes stirrup diameter) were used in accordance with the provisions in Chinese codes [15] to resist torsion. The thickness of concrete cover was $20 \mathrm{~mm}$. In addition, before the second casting in the second test group, the top surface of the first cast concrete was manually roughened and cleaned to ensure a reliable bond between the concrete-to-concrete interface.

Three batches of commercial concrete were used, i.e., the concrete in the first test group, in the first casting and second casting in the second test group. They had uniaxial compressive strengths of 30.2 , 25.7 and $35.0 \mathrm{MPa}$, and elasticity moduli of $3.2 \times 10^{5}, 3.0 \times 10^{5}$ and $3.2 \times 10^{5} \mathrm{MPa}$, respectively. The uniaxial tensile strengths of the second and third batch concrete were 3.1 and $4.1 \mathrm{MPa}$, respectively. The mechanical properties of reinforcing steel bars are presented in Table 2. Bar grades of HPB and HRB were plain ground and deformed steel bars, and used for stirrups and longitudinal reinforcement, respectively.

Fig. 4 illustrates the test setup developed by the third author. Both ends of each specimen were placed on the arc-shaped supports. A shallow groove was carved in the steel plate of the support and filled with steel balls to approximately implement friction-free rotation of the supports. The loads to generate torsional moment were applied at each beam end using a jack, an upper steel reaction beam and two steel pull rods. By doing this, two jacks were in opposite lateral sides of a beam and gradually exerted forces to generate pure torsion. The arm length of the forces was $0.31 \mathrm{~m}$ in an unloading condition and slightly varied during the loading process due to the rotation of the transverse beam. This variation was believed to be too small to be appreciable and was, therefore, ignored. The exerted pure torsions equal the applied forces time the arm length of $0.31 \mathrm{~m}$. In addition, four AccuStar electric inclinometers were fastened on the upper surface of each specimen to monitor the angles of twist, as illustrated in Fig. 3. The inclinometers had a measurement range of $\pm 45^{\circ}$ and an accuracy of $0.001^{\circ}$. Force control mode was first used to estimate peak forces and later transferred to the displacement control mode. Forces, displacements and angles of twist were automatically recorded using a data acquisition device.

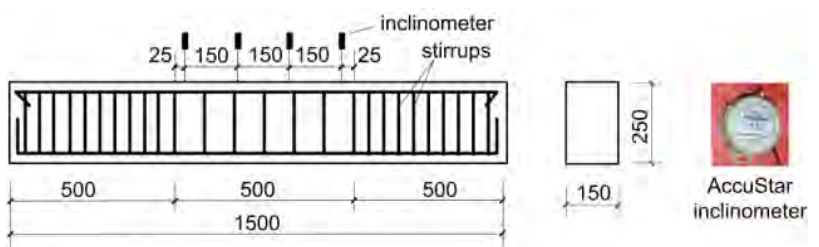

Fig. 3 Arrangement of stirrups in longitudinal direction

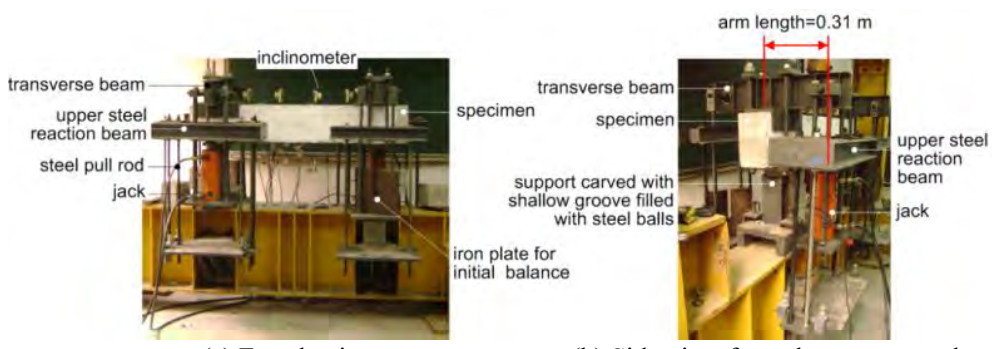

(a) Façade view

(b) Side view from the support end

Fig. 4 Test setup 
Table 2. Mechanical properties of reinforcing steel bars

\begin{tabular}{cccc}
\hline $\begin{array}{c}\text { Diameter }(\mathrm{mm}) \\
\text { and [bar grade* }\end{array}$ & $\begin{array}{c}\text { Yield strength } \\
(\mathrm{MPa})\end{array}$ & $\begin{array}{c}\text { Ultimate strength } \\
(\mathrm{MPa})\end{array}$ & $\begin{array}{c}\text { Elasticity modulus } \\
\left(\times 10^{5} \mathrm{MPa}\right)\end{array}$ \\
\hline D8[HPB] & 386 & 517 & 2.0 \\
D10[HPB] & 301 & 432 & 1.9 \\
D12[HPB] & 371 & 502 & 1.8 \\
D12[HRB] & 428 & 618 & 2.1 \\
D16[HRB] & 384 & 594 & 1.8 \\
\hline D8[HPB] & 432 & 629 & 2.1 \\
D10[HPB] & 392 & 569 & 2.1 \\
D12[HPB] & 395 & 557 & 2.1 \\
D12[HRB] & 414 & 623 & 2.1 \\
D16[HRB] & 395 & 581 & 2.1 \\
\hline
\end{tabular}

Note: "Bar grades of HPB and HRB mean plain ground and deformed steel bars, respectively.

\section{EXPERIMENTAL RESULTS AND ANALYSIS}

\subsection{Failure characteristics}

Table 3 presents the common failure characteristics of the specimens under torsion [18] and the specific behavior of composite beams. For example, Fig. 5 illustrates the failure profile of specimen B1. First, initial cracking at an angle of $45^{\circ}$ occurred in the middle region of two lateral surfaces of the specimens. These cracks developed in length,and more inclined cracks gradually appeared in the two lateral, upper and lower surfaces. These cracks then extended and connected to each other to form spiral cracks around the beam perimeter with approximately identical intervals in longitudinal direction. In addition, compared to specimens with appropriately reinforced failure (e.g., A1, B1, C1, D1 and E1), overreinforced specimens (e.g., specimens A3, B3, C3, D3 and E3) had a relatively large number of fine cracks. In addition, concrete spalling off at the specimen corners was found for some specimens, as typically illustrated in Fig. 6. Spalling off at corners is an occasional phenomenon particularly for specimens with relatively large stirrup spacing. Finally, horizontal cracks were found in lateral surfaces along the concrete-to-concrete interface of all composite specimens, as illustrated in Fig. 6. The crack lengths tended to increase with the increase in maximum torques. This specific behavior of horizontal cracks was only observed for composite beams, which indicated that concrete-to-concrete interfaces were the weaker regions and casting at different times influenced the torsional behavior of RC beams.

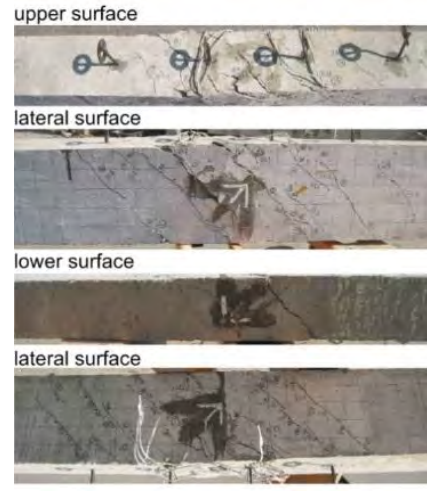

Fig. 5 Failure profile of specimen B1
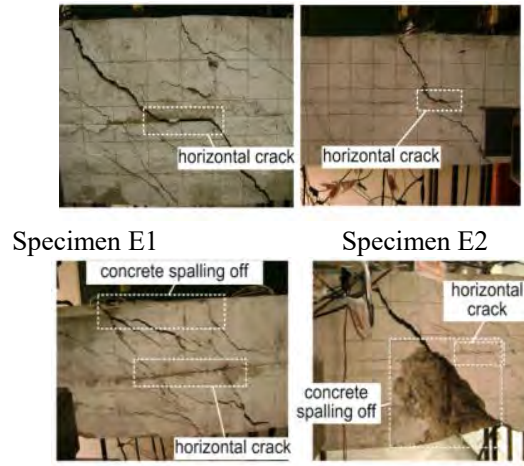

Specimen E3

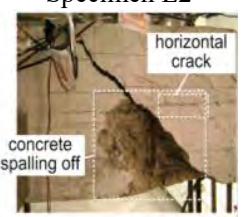

Specimen E4

Fig. 6 Spalling off of concrete at beam corners and horizontal cracks along the concrete-to-concrete interfaces 
Table 3 Failure characteristic and tested maximum torques $T_{\mathrm{u} \text {, test }}$

\begin{tabular}{|c|c|c|c|c|}
\hline $\begin{array}{l}\text { Test } \\
\text { group }\end{array}$ & $\begin{array}{l}\text { Specimer } \\
\text { no. }\end{array}$ & $\begin{aligned} T_{\mathrm{u}, \text { test }} \\
(\mathrm{kN} \cdot \mathrm{m})\end{aligned}$ & $\begin{array}{c}\text { Percentage } \\
\text { differential } \\
(\%)\end{array}$ & $\begin{array}{c}\text { Failure } \\
\text { characteristics }\end{array}$ \\
\hline \multirow[t]{12}{*}{1} & A1 & 12.0 & - & principle crack, concrete spalling off at corner \\
\hline & B1 & 11.0 & -8.3 & principle crack \\
\hline & $\mathrm{C} 1$ & 10.8 & -10.0 & principle crack \\
\hline & A2 & 11.0 & - & principle crack, concrete spalling off at corner \\
\hline & B2 & 10.4 & -5.4 & principle crack, concrete spalling off at corner \\
\hline & $\mathrm{C} 2$ & 8.4 & -23.6 & principle crack \\
\hline & A3 & 16.5 & - & fine cracks \\
\hline & B3 & 16.5 & 0.0 & fine cracks, concrete spalling off at corner \\
\hline & $\mathrm{C} 3$ & 13.6 & -17.6 & fine cracks, \\
\hline & A4 & 8.3 & - & fine cracks, principle crack \\
\hline & B4 & 8.2 & -1.2 & fine cracks, principle crack, concrete spalling off at corner \\
\hline & $\mathrm{C} 4$ & 7.6 & -8.4 & fine cracks, principle crack \\
\hline \multirow[t]{8}{*}{2} & D1 & 8.4 & - & principle crack, concrete spalling off at corner \\
\hline & E1 & 9.5 & 13.1 & principle crack, concrete spalling off at corner, $l_{\mathrm{h}}{ }^{*} \approx 100 \mathrm{~mm}$ \\
\hline & $\mathrm{D} 2$ & 8.1 & - & principle crack, concrete spalling off at corner \\
\hline & E2 & 8.5 & 5.0 & principle crack, $l_{\mathrm{h}} \approx 60 \mathrm{~mm}$ \\
\hline & D3 & 10.2 & - & fine cracks, concrete spalling off at corner \\
\hline & E3 & 10.8 & 5.9 & fine cracks, concrete spalling off at corner, $l_{\mathrm{h}} \approx 400 \mathrm{~mm}$ \\
\hline & $\mathrm{D} 4$ & 7.6 & - & fine cracks, principle crack, concrete spalling off at corner \\
\hline & E4 & 7.8 & 2.6 & $\begin{array}{l}\text { fine cracks, principle crack, concrete spalling off at corner, } \\
\qquad l_{\mathrm{h}} \approx 100 \mathrm{~mm}\end{array}$ \\
\hline
\end{tabular}

Note: ${ }^{*} l_{\mathrm{h}}$ means the length of the horizontal crack along concrete-to-concrete interface in composite beams.

\subsection{Maximum torque}

Table 3presents the maximum torques of the specimens. It was found that the stirrup forms influenced the maximum torques. In the first test group, the maximum torques of the beams reinforced with two-piece enclosed stirrups (B-series specimens) slightly decreased compared to those with conventional stirrups (A-series specimens) in a range from $-8.3 \%$ to $0 \%$ with a mean value of $-3.7 \%$. For the beams reinforced with U-stirrups (C-series specimens), the average percentage decrease of the maximum torques was $-14.9 \%$ compared to those of A-series specimens. In addition, in the second test group, the maximum torques of composite beams were greater than those of monolithically cast beams thanks to the relatively high strength of the second cast concrete. The percentage increase of the maximum torques of E-series specimens ranged from $2.6 \%$ to $13.1 \%$ with a mean value of $6.7 \%$ compared to those of D-series specimens.

\subsection{Torque-twist response}

Fig. 7 presents the typical torque-twist responses for specimens A1, B1, C1, D1 and E1. In the figures, the angle of twist per unit length (unit: $\mathrm{rad} \cdot \mathrm{m}-1$ ) was obtained by calculating the ratio of the angle differential measured within the two most outer inclinometers to their distance. Evidently, these curve shapes were typical for RC beams under torsion as described in textbooks [18]. In addition, insignificant effects of stirrup form and casting times on the deformation capacities were found. 

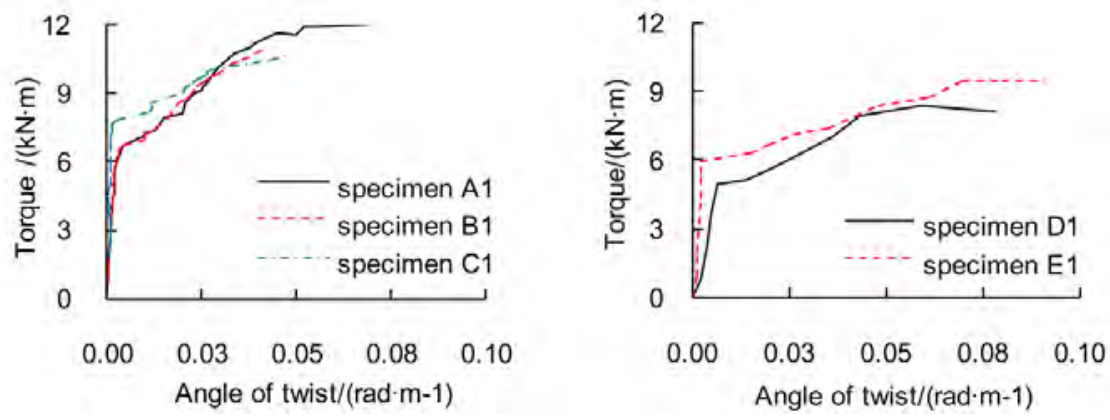

Fig. 7 Torque-twist responses of specimens A1, B1, C1, D1 and E1

\section{DISCUSSION}

Three aspects regarding the test results were discussed: i) reasons for the variation of maximum torques caused by different stirrup forms and cast times, ii) limitation of test results, and iii) design values of torsional strength.

\subsection{Reasons for the variation of maximum torques}

For composite beams reinforced with two-piece enclosed stirrups, their maximum torques were affected by three specific factors compared to those of monolithically cast beams reinforced with conventional stirrups.

Among the three factors, the first two ones helped to increase and the third one tended to decrease their maximum torques. First, the two connections between a U-stirrup and a crosstie exit around the stirrup perimeter. This is different from the case of conventional beams, which only have one connection. This factor probably led to a decrease in the maximum torques of concern. The effect can be interpreted using the space truss analogy. That is, after concrete cracking, the torque is mainly resisted by a thinwalled tube around the four lateral surfaces of a RC beam with rectangular cross section. The thin-walled tube contains longitudinal reinforcement, closed stirrups and concrete compression diagonals. As illustrated in Fig. 8, the compressive components of concrete acting toward the corner are balanced by tensions in stirrups. The concrete outside the reinforcing cage is not well anchored, and the shaded region will spall off if the compression in the outer shell is large or the stirrup spacing is large. However, the situation becomes even worse for the beams reinforced with two-piece enclosed stirrups after concrete spalling. Their stirrup hooks can not be well anchored compared to the case of a continuous stirrup, as illustrated in Fig. 8. This detrimentally affects the structural integration of the space truss to resist torsion and leads to the decrease of maximum torques. Note that concrete spalling at the tube corners generally occurs when the torque approaches its peak value. Thus, the decrease of the maximum torques of the beams reinforced with two-piece enclosed stirrups is insignificant compared to those with conventional stirrups.

Second, horizontal interface is generated between the first and second cast concrete and can crack under torsion in tests. The lengths of the horizontal cracks tend to increase as the tested maximum torques increase. The cracking behavior of the concrete-to-concrete interface detrimentally affects the structural integration and is probably a reason to decrease the maximum torque of an $\mathrm{RC}$ beam. To prevent the interface from premature cracking, measurements used to improve the interface performance should be considered, e.g., using cohesive materials or tie reinforcements vertically across the interface.

Finally, in the second test group, concrete with relatively high compressive strength was used for the second casting compared to that for first casting. This is commonly suggested in the codes, e.g., the American code [17], European code [16] and Chinese code [15]. For each composite beam used in this study, the height of the second cast concrete is about half of the overall beam height. As is generally 
known, the maximum torque of an $\mathrm{RC}$ beam increases as its concrete strength increases. The authors believed that this factor is the main reason for the relatively high maximum torques of E-series specimens (i.e., composite beams reinforced with two-piece enclosed stirrups) compared to those of D-series specimens (i.e., monolithically cast beams reinforced with two-piece enclosed stirrups).

\subsection{Limitation of test results}

The proportion of the second cast concrete to the overall concrete in each beam was relatively large regarding the beams actually used in practice. This is a limitation of the test results and can lead to an overestimation of the maximum torques when using the test results in practice. The height of the second cast concrete (approximately $125 \mathrm{~mm}$ in tests) with relatively high quality was about half of the beam height $(250 \mathrm{~mm})$. Generally, on construction sites, the heights of the second cast concrete range from 100 $\mathrm{mm}$ to $150 \mathrm{~mm}$ while the beam heights are much more than $250 \mathrm{~mm}$. Thus, the contribution of the second cast concrete to the overall torsional resistance can be appropriately decreased compared to those cases in the tests.

\subsection{Design values of torsional strength}

Test results of the second test group revealed that the maximum torques of composite beams (E-series specimens) were on average $6.7 \%$ greater than those of monolithically cast beams (D-series specimens). In the first test group of monolithically cast beams, the specimens reinforced with two-piece enclosed stirrups (B-series specimens) were on average 3.7\% smaller than those of the beams reinforced with conventional stirrups (A-series specimens). Consequently, the maximum torques and design values of torsional strength of E-series specimens are approximately equal to those of A-series specimens. The recommended design methods in relevant codes (e.g., [15-17]) were suggested to maintain their applicability for computing the design values of torsional strength.

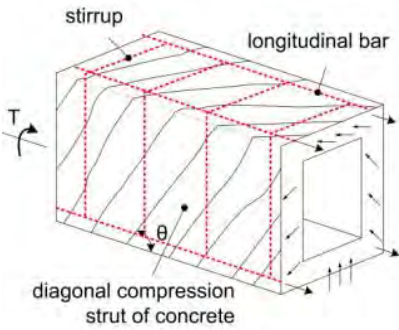

(a) Space truss analogy

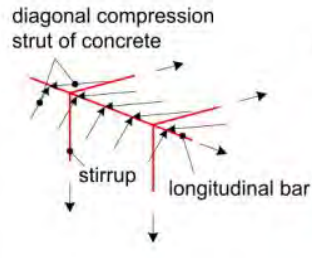

(b) Force at a corner of the space truss

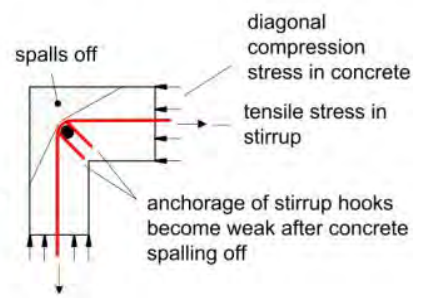

(c) Spalling at a corner of the space truss

Fig. 8 Concrete spalling at a corner and its effect on closed stirrups

\section{CONCLUSIONS}

Torsional behavior of composite $\mathrm{RC}$ beams that are cast twice and reinforced with two-piece enclosed stirrups was investigated. Test variables of stirrup form and casting times were considered and their effects on the torsional behavior of the beams were separately studied in two test groups. Minor differences were observed between the torsional behavior of composite beams reinforced with two-piece enclosed stirrups and those of monolithically cast beams reinforced with conventional stirrups. These observations were attributed to the three factors between the two types of beams. That is, i) two connections exist around the perimeter of a two-piece enclosed stirrup whereas only one connection is present in conventional stirrups, ii) horizontal cracks occur along the concrete-to-concrete interfaces in composite beams under torsion, and iii) second cast concrete on the upper portion of composite beams has relatively high strength compared to that of the first cast concrete on the lower portion of the beams. The first two factors decreased and the third one improved the torsional strengths of the RC beams under 
consideration. It was also suggested that design values of torsional strength for composite RC beams reinforced with two-piece enclosed stirrups were approximately equal to those of monolithically cast beams reinforced with conventional stirrups.

\section{REFERENCES}

[1] Elliott K S, "Precast concrete structures", Oxford: Butterworth-Heinemann, UK, 2005.

[2] Vidjeapriya R, Vasanthalakshmi V, Jaya K.P, "Performance of exterior precast concrete beamcolumn dowel connections under cyclic loading", International Journal of Civil Engineering, 12(1): 82-95, 2014.

[3] Štimac GI, Grandić D, Bjelanović A, "Evaluation of torsional stiffness in beam and slab bridge decks based on load testing", International Journal of Civil Engineering, 13(3):255-266, 2015.

[4] Lin F, Zhong Q, Zhang Z, "Flexural behaviour of RC beams reinforced with compressive steel bars and two-piece enclosed stirrups", Construction and Building Materials, 126:55-65, 2016.

[5] Lessig NN, "Theoretical and experimental investigation of reinforced concrete elements subjected to combined bending and torsion", Theory of design and construction of reinforced concrete structures, Moscow, 73-84, 1958.

[6] Yudin VK, "Determination of the load-carrying capacity ofrectangular reinforced concrete elements subjected to combined torsionand bending", Concrete and Reinforced Concrete (Beton $i$ Zhelezo beton), 6. Moscow, 265-269, 1962.

[7] Rausch E, "Design of reinforced concrete for torsion and shear (Berechung des Eisenbeton gegen Verdrehung und Abscheren)", Ph. D dissertation, Technische Hochschule, Berlin, Germany, 1929.

[8] Lampert P, Thulimann B, "Torsions Versuch an Stahlbetonbalken (torsion test on reinforced concrete beams)". Report no. 6502-2, Institution Fuer Baustatik, ETH, Zurich, Switzerland, 1968.

[9] Collins MP, "Torque-twist characteristics of reinforced concrete beams. Inelastic and nonlinearity in structural concrete", University of Waterloo Press, Waterloo, Ontario, Canada, pp 211-231, 1973.

[10] Hsu TT, Mo YL, "Softening of concrete in torsional members-theory and tests", Journal of the American Concrete Institute, 82(3):290-303, 1985.

[11] Bernardo LFA, Lopes SMR, "Behavior of concrete beams under torsion - NSC plain and hollow beams", Materials \& Structures, 41(6):1143-1167, 2008.

[12] Bernardo LFA, Andrade JMA, Lopes SMR, "Modified variable angle truss-model for torsion in reinforced concrete beams", Materials \& Structures, 45(12): 1877-1902, 2012.

[13] Bernardo LFA, Andrade JMA, Nunes NCG, "Generalized softened variable angle truss-model for reinforced concrete beams under torsion”, Materials \& Structures, 48(7): 2169-2193, 2015.

[14] Jeng CH, "Unified softened membrane model for torsion in hollow and solid reinforced concrete members: modeling precracking and postcracking behavior", Journal of Structural Engineering, 141(10): 04014243, 2014.

[15] Ministry of Housing and Urban-Rural Development of the People's Republic of China, "Code for design of concrete structures (GB50010-2010)", Beijing, China, 2010.

[16] European Committee for Standardization, "Eurocode 2: Design of concrete structures-part 1-1: general rules for buildings (EN 1992-1-1)", Brussels, Belgium, 2010.

[17] American Concrete Institute Committee 318, "Building code requirements for reinforced concrete (ACI318-11)", American Concrete Institute, Farmington Hills, MI, 2011.

[18] Wight JK, MacGregor JG, "Reinforced Concrete: Mechanics and design (6thed.)", Pearson Prentice Hall, Upper Saddle River, NJ, 2005. 